Article

\title{
Wood Density Determination by Drilling Chips Extraction in Ten Softwood and Hardwood Species
}

\author{
Roberto D. Martínez $1, * \mathbb{(}$, José-Antonio Balmori ${ }^{1}\left(\mathbb{D}\right.$, Daniel F. Llana ${ }^{2,3}{ }^{(1)}$ and \\ Ignacio Bobadilla ${ }^{3,4}$ \\ Timber Structures and Wood Technology Research Group, UVa, 47014 Valladolid, Spain; balmori@arq.uva.es \\ Timber Engineering Research Group, NUI Galway, H91HX31 Galway, Ireland; danielfllana@gmail.com \\ Timber Construction Research Group, UPM, 28040 Madrid, Spain; i.bobadilla@upm.es \\ 4 Department of Forest and Environmental Engineering and Management, MONTES (School of Forest \\ Engineering and Natural Resources), Universidad Politécnica de Madrid, 28040 Madrid, Spain \\ * Correspondence: robertomartinez@arq.uva.es
}

Received: 19 February 2020; Accepted: 26 March 2020; Published: 27 March 2020

\begin{abstract}
Research Highlights: The novelty of this study is the development of an accurate wood density estimation method based on a relatively brand new semi-destructive testing technique (drilling chips extraction). This method is especially crucial in the assessment of existing timber structures. Background and Objectives: Probing, drilling, and coring are non-destructive and semi-destructive techniques commonly used for timber density estimation in existing timber structures. Most of these techniques show poor or medium accuracy or are so expensive or destructive. This paper aims to obtain accurate estimation models for wood density in existing structures using the easy to use drilling chips extraction technique. Materials and Methods: 300 specimens $\left(95 \times 65 \times 200 \mathrm{~mm}^{3}\right)$ from ten softwood and hardwood species covering a wide range of density (from 350 to $980 \mathrm{~kg} \cdot \mathrm{m}^{-3}$ ) were tested after conditioning. The Wood Extractor device based on the drilling chips extraction technique was used in the radial and the tangential direction. Mass of the chips collected (drilling residue) from each drill was recorded. Results: Density obtained from drilling residue was not statistically significantly different between radial and tangential directions avoiding take into account direction when measuring. The density obtained in the whole specimens is slightly higher than the density obtained by drilling residue being this difference uniformly through the range of densities studied. Two different estimation models were presented with high determination coefficients $(96 \%$ and 97\%) and low standard errors. These results were similar to those obtained by other authors using core drilling but causing less damage. Conclusions: Drilling chips extractor is a simple, reliable and inexpensive method to estimate density in existing structures with accuracy.
\end{abstract}

Keywords: non-destructive testing; semi-destructive testing timber structures assessment; Wood Extractor

\section{Introduction}

To retrofit the existing timber structures with renovation and restoration works, it is previously necessary the characterization of wood singularities (knots, cracks, etc.), biologic degradation, and the estimation of the mechanical properties [1-6]. Non-destructive and semi-destructive testing (NDT/SDT) includes accurate, dependable and easy to use techniques for estimation of timber mechanical properties in the assessment of existing timber structures [7-11].

Many researchers combine several NDT techniques results to increase accuracy and safety in the evaluation of timber structures [12-16]. Density is probably the essential property estimated because it is closely correlated with other wood mechanical properties $[17,18]$, and it has been traditionally 
considered a fundamental parameter as a wood quality indicator [19]. Furthermore, combining wood density with other NDT results, as the velocity of acoustic wave propagation, dynamic modulus of elasticity is calculated [20-25].

There are several NDT techniques, sometimes considered SDT, to estimate wood density [2628]. However, its application over exiting timber structures sometimes is difficult, and these local measurements show medium correlation with the real densities.

The pullout resistance technique using the commercial device Screw Withdrawal Resistance Meter (Fakopp, Sopron, Hungary), has been extensively used to estimate density over existing timber structures for a long time. However, low determination coefficients $\left(r^{2}\right)$ with values from $50 \%$ to $67 \%$ [29-31] are achieved by this technique. The needle penetration resistance technique, which relates the wood resistance to insert a needle with a constant force to wood density, has been used initially on forest works to estimate the density on standing trees, with a commercial tool as Pilodyn (Proceq, Schwerzenbach, Switzerland) [32,33]. This technique was also used on timber structures, thought its results showed scattered $r^{2}$, from $50 \%$ to $61 \%$ achieved on softwoods [34,35], to values from 0.75 to 0.84 reported on hardwoods [36].

Another NDT technique less commonly used to estimate wood density is the infrared thermography. Nevertheless, some parameters, as the influence of knots or fissures, are still not well defined; this technique achieves over clean wood values of $r^{2}$ upper to $90 \%$ [37].

This $r^{2}$ scattered in results has generated new investigations to achieve and develop more reliable tools to estimate wood density. Resistograph techniques show as the most accurate tool to estimate local wood density, with a value of $r^{2}$ in a range from $80 \%$ to $90 \%$ [38-40]. This complex, and expensive, the equipment uses a small drill that penetrates inside the wood with a constant speed, recording the wood resistance to the penetration allowing density estimation [41,42]. The core drilling technique (CDT) is an inexpensive method based on the obtention of wood samples making a small hollow drill. This technique has been widely used on standing trees to determine differences in physical and mechanical properties as density or moisture content (MC) with good results [43-45]. The $r^{2}$ of this technique achieves values upper to $80 \%[2,39]$ and in some assessment of softwood timber structures an $r^{2}$ of $89 \%$ was reported $[46,47]$.

In the present study, a relatively brand new SDT device to estimate wood density using the drilling residue is analyzed. The Wood Extractor [48] not only estimates density from duster residue collected from drilling but also estimates MC. Previous studies using pine species showed an $r^{2}$ of $84 \%[49,50]$.

There are currently no simple, economical, reliable and accurate NDT or SDT methods that can estimate wood density in a wide range of density values. The drilling residue technique meets these parameters, but there are no data available for very low or high wood densities.

Besides, this drilling chips extraction technique has a potential application in forestry to estimate the density of standing trees. Current device has been developed to estimate wood density under conditions of wood MC below the fiber saturation point. However, with a little adaptation, this device could also be used to measure on greenwood (trees). Our preliminary tests showed promising results [51]. This paper aims to obtain reference values to estimate wood density in existing structures using the drilling chips extraction technique. Being able to use in the entire spectrum of densities used in construction and without species identification.

\section{Materials and Methods}

\subsection{Drilling Residue Collection Device}

The Wood Extractor device developed and patented by Martínez, and Bobadilla [48] has been used to estimate the density of wood. This device was designed to be coupled to a commercial power drill to collect all the waste that is produced during drilling in a single-use paper bag filter [50]. This device involves setting drill diameter $(8 \mathrm{~mm})$ and depth $(47.7 \mathrm{~mm})$, giving a known removed volume of wood $\left(2.4 \mathrm{~cm}^{3}\right)$. After drilling and the collection of residues in the filter, the sample is weighed to 
estimate wood density according to Equation (1). The operation of the device is based on harnessing the movement of air produced by the turbine of a conventional drill to suck up the chips produced by drilling a hole and encapsulating them in a one-use filter (0.22 g constant mass of filter) (Figure 1).

$$
\rho=\mathrm{m} / \mathrm{v}
$$

Because the chips and dust generated during drilling are absorbed and stored in the filter bag, the worker doesn't need special protective equipment, unlike what is stated in the CDT [52].

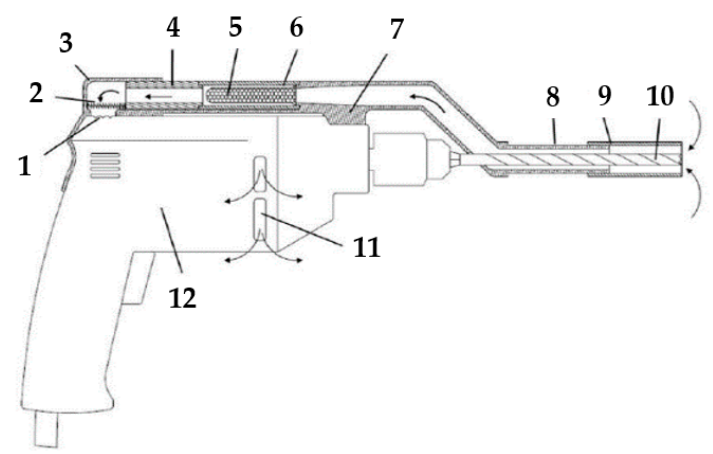

Figure 1. Cross-section view of the Wood Extractor device. Main components: 1 air intake, 2 spring, 3 enveloping structure, 4 telescopic tube, 5 paper filter bag, 6 cartridge, 7 clamp, 8 coaxial pipes, 9 telescopic system, 10 drill bit, 11 side holes, 12 power drill. The arrows indicate airflow.

\subsection{Wood Specimens}

Density estimation was carried out on 300 pieces from ten softwoods and hardwoods commonly used in construction in Spain with an extensive density distribution (350 to $980 \mathrm{~kg} \cdot \mathrm{m}^{-3}$ ), (Table 1). 30 specimens were tested per species with dimensions of $95 \times 65 \times 200 \mathrm{~mm}^{3}$.

Table 1. Common and Botanical names of wood species tested.

\begin{tabular}{ccc}
\hline Number & Common Name & Botanical Name \\
\hline 1 & Western red cedar & Thuja plicata Donn ex D.Don \\
2 & Black poplar & Populus x euroamericana (Dade) Guinier \\
3 & Radiata pine & Pinus radiata D. Don \\
4 & Maritime pine & Pinus pinaster Ait. ssp. mesogeensis Fieschi \& Gaussen \\
5 & Scots pine & Pinus sylvestris L. \\
6 & Salzmann pine & Pinus nigra Arnold. ssp. salzmannii (Dunal) Franco \\
7 & Sweet chestnut & Castanea sativa Mill. \\
8 & European oak & Quercus robur L. \\
9 & Iroko & Milicia excelsa (Welw.) C.C. Berg. \\
10 & Missanda & Erythrophleum Afzel ex G. Don Sp. \\
\hline
\end{tabular}

\subsection{Density Estimation}

Conditioned specimens, in a climatic chamber at $20 \pm 2{ }^{\circ} \mathrm{C}$ and $65 \pm 5 \%$ relative humidity (approx. $12 \%$ equilibrium moisture content), were sized with a resolution of $0.01 \mathrm{~mm}$ and weighed with a resolution of $0.01 \mathrm{~g}$ to obtain their density according to Equation (1); where $\rho$ is the density in $\mathrm{kg} \mathrm{m}^{-3}$, $\mathrm{m}$ is the mass in $\mathrm{kg}$ and $\mathrm{v}$ is the volume in $\mathrm{m}^{3}$.

Two tests per specimen were performed following the methodology described in Martínez et al. [51], one in radial direction and another in tangential direction. The location of the tests is shown in Figure 2. Each extraction was weighed with a resolution of $0.01 \mathrm{~g}$, and the diameter and depth of each hole were measured with a resolution of $0.01 \mathrm{~mm}$. For each sample, the density of the wood extracted in each of the holes was calculated according to Equation (1), using the nominal volume of the hole and the mass of the chips removed, discounting the mass of the filter. 


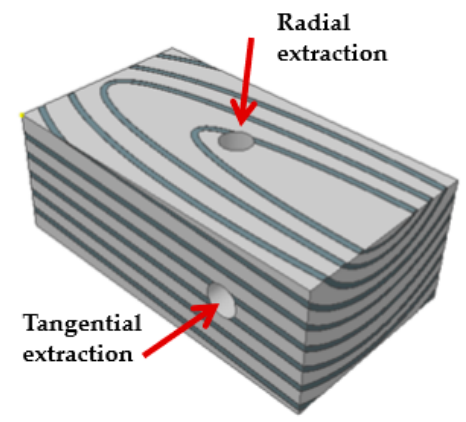

Figure 2. Specimen and sampling locations.

\section{Results and Discussions}

The mean density values $(\rho)$ of the specimens and drilling residue and their coefficients of variation (COV) are listed in Table 2. A higher COV for pine species (around 9\%) than for the other species (about $4 \%$ ) was reported. This higher COV may be due to the significant differences between sapwood and heartwood proportions in the pine specimens and the high resin content typical of maritime pine.

Table 2. Average densities of specimens and drilling residue.

\begin{tabular}{|c|c|c|c|c|c|c|c|c|}
\hline \multirow[b]{3}{*}{ Sp. } & & & \multicolumn{6}{|c|}{ Drilling Residue Density $(\rho)$} \\
\hline & \multicolumn{2}{|c|}{$\begin{array}{l}\text { Specimens } \\
\text { Density }(\rho)\end{array}$} & \multicolumn{2}{|c|}{$\rho$ Radial } & \multicolumn{2}{|c|}{$\rho$ Tangential } & \multicolumn{2}{|c|}{$\rho$ Mean } \\
\hline & $\begin{array}{c}\text { Mean } \\
\left(\mathrm{kg} \cdot \mathrm{m}^{-3}\right)\end{array}$ & $\begin{array}{c}\mathrm{COV} \\
(\%)\end{array}$ & $\begin{array}{c}\text { Mean } \\
\left(\mathrm{kg} \cdot \mathrm{m}^{-3}\right)\end{array}$ & $\begin{array}{l}\mathrm{COV} \\
(\%)\end{array}$ & $\begin{array}{c}\text { Mean } \\
\left(\mathrm{kg} \cdot \mathrm{m}^{-3}\right)\end{array}$ & $\begin{array}{c}\text { COV } \\
(\%)\end{array}$ & $\begin{array}{c}\text { Mean } \\
\left(\mathrm{kg} \cdot \mathrm{m}^{-3}\right)\end{array}$ & $\begin{array}{c}\text { COV } \\
(\%)\end{array}$ \\
\hline Western red cedar & 347 & 1.7 & 336 & 5.5 & 352 & 3.7 & 344 & 2.5 \\
\hline Black poplar & 504 & 2.4 & 485 & 3.6 & 497 & 4.9 & 491 & 3.5 \\
\hline Radiata pine & 476 & 8.9 & 465 & 9.9 & 455 & 11.8 & 461 & 9.7 \\
\hline Maritime pine & 543 & 9.6 & 507 & 10.0 & 516 & 9.9 & 511 & 9.6 \\
\hline Scots pine & 573 & 6.3 & 533 & 9.6 & 542 & 11.9 & 538 & 9.7 \\
\hline Salzmann pine & 585 & 12.1 & 567 & 13.2 & 562 & 12.6 & 565 & 12.7 \\
\hline Sweet chestnut & 615 & 7.7 & 580 & 9.1 & 590 & 8.4 & 585 & 8.5 \\
\hline European oak & 672 & 3.5 & 664 & 5.0 & 681 & 4.3 & 673 & 4.2 \\
\hline Iroko & 617 & 5.0 & 558 & 6.0 & 544 & 6.4 & 551 & 5.7 \\
\hline Missanda & 975 & 1.2 & 937 & 1.9 & 935 & 2.3 & 936 & 1.9 \\
\hline Average of all & 593 & 27.1 & 561 & 27.6 & 568 & 27.1 & 566 & 27.2 \\
\hline
\end{tabular}

Normality was verified for each variable. No significant differences between radial and tangential drilling residue densities at 95\% confidence level (ANOVA $p$ value $=0.9245$ ) were found (Figure 3). Martínez et al. (2018) declared similar findings in the case of pine species. CDT, pullout resistance and needle penetration resistance measurements also showed no differences [29,46,52,53].

Since there was no statistically significant difference between the densities of the residues in the radial and tangential direction, from now on, the study was carried out with the average of both values. 


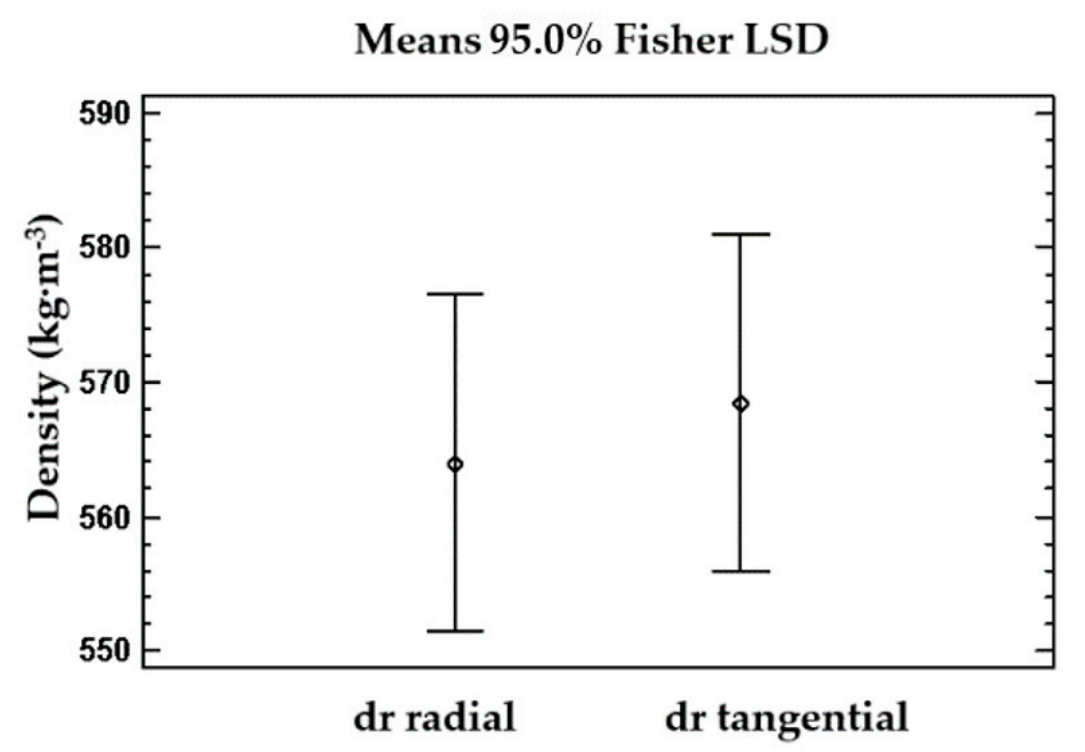

Figure 3. Means plot of density of drilling residues(dr) from radial and tangential holes.

Table 2 and Figure 4 show slightly lower drilling residues densities than specimen densities except for European oak. Drilling residue density was on average $4 \%$ lower than specimen density, and there was not a statistically significant difference between the two values measured (ANOVA $p$ value $=$ 0.0525), with a level of confidence of $95 \%$. Similar behaviour was reported by Martínez et al. [50] whose explanation was: "This may be mainly due to three reasons: first, there is a possible loss of material (wood dust) during drilling; second, moisture is lost from drilling residue due to the increased temperature caused by friction between the bit and wood; and finally, when a hole is drilled in wood the bit produces a transversal embedment compression perpendicular to the grain in the inner walls of the hole, so the extracted volume of wood is less than the volume of the hole".

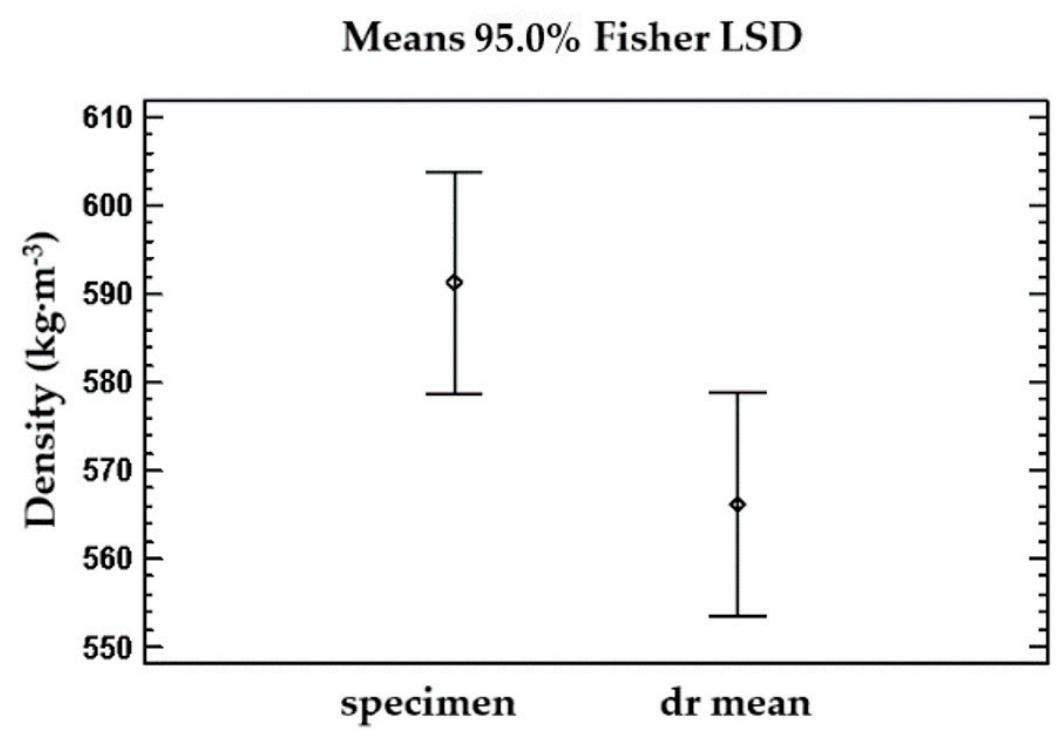

Figure 4. Means plot of density obtained by specimens and by drilling residues.

As is shown in Figure 5, the centre of the distribution of variation of the density (around 0.96) between the drilling residues and the specimens is uniformly distributed throughout all the densities studied. It can be concluded that the loss of mass during the extraction of the drilling residues is constant and does not depend on the density of the specimen. 


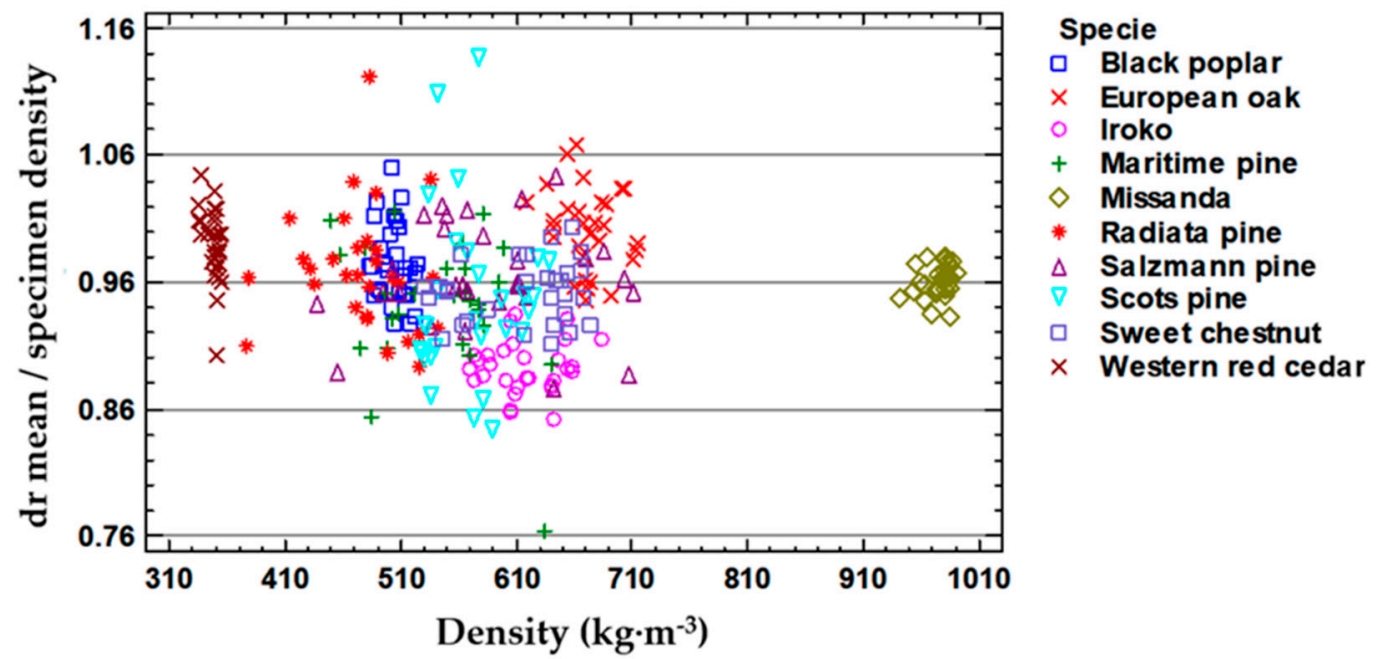

Figure 5. Distribution plot of the ratio of dr density/specimen density depending on the specimen's density.

Taking into account that the volume used to calculate the drilling residue density is constant (nominal volume of the hollow), the authors propose a regression model to correlate the mass of the chips collected during drilling including the filter bag and the specimen density. A robust statistical relationship between the average of radial and tangential drilling residue mass and the specimen mass was found ( $p$-value $<0.002)$. Therefore, a linear regression model to estimate specimen density using drilling residue mass as a predictor variable was developed.

The assumptions of normality, homoscedasticity and linearity were tested. The resulting model is shown in Equation (2) and Figure 6.

$$
\rho=433.372 \cdot \mathrm{dr}_{\text {mean }}-105.816 \quad r^{2} 97.38 \% \text {, StE } 26.07 \mathrm{~kg} \cdot \mathrm{m}^{-3}
$$

where " $\rho$ " is the specimen density in $\mathrm{kg} \mathrm{m}^{-3}$ and " $\mathrm{dr}_{\text {mean }}$ " is the drilling residue mean mass in $\mathrm{g}$ (including the filter bag). StE is the standard error. The relation is significant at a confidence level of $95 \%$.

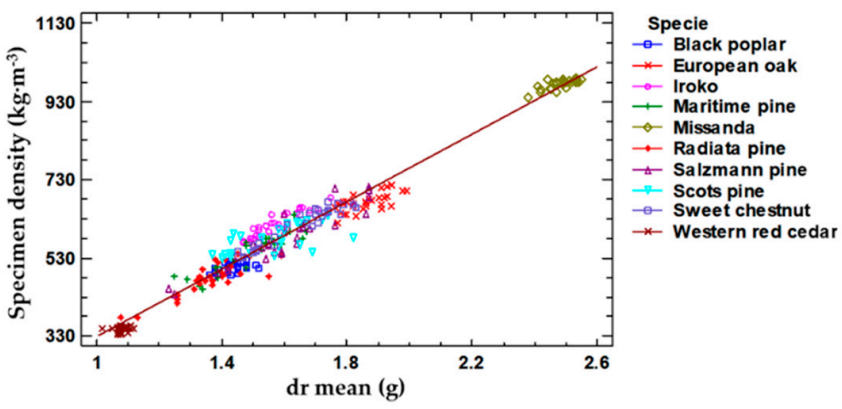

(a)

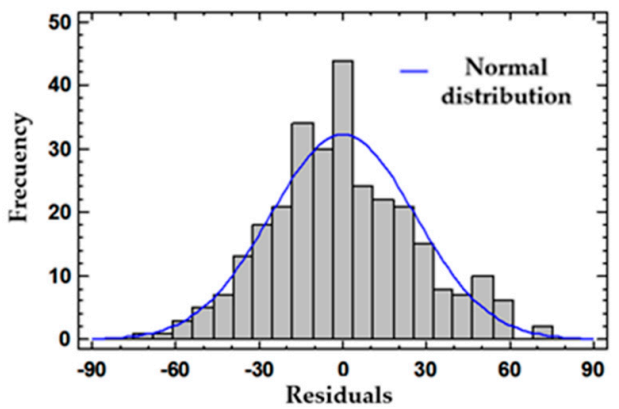

(b)

Figure 6. Linear regression between specimen density and drill residue mass mean of radial and tangential results. (a) Plot of the fitted model; (b) Frequency histogram of the model residuals.

In the previous model, two measurements in radial and tangential direction are needed. In the assessment of existing timber structures, the test direction is usually unknown, and it is difficult to have access to more than one face of the timber element. As no statistically significant differences between radial and tangential direction were found, a new estimation model using all mass values without taking into account the test direction was developed. 
The assumptions of normality, homoscedasticity and linearity were tested. The resulting model is shown in Equation (3) and Figure 7.

$$
\rho=428.66 \cdot \mathrm{dr}-97.593 \quad r^{2} 96.26 \%, \mathrm{StE} 31.01 \mathrm{~kg} \cdot \mathrm{m}^{-3}
$$

where " $\rho$ " is the specimen density in $\mathrm{kg} \mathrm{m}^{-3}$ and " $\mathrm{dr}$ " is the drilling residue mass in $\mathrm{g}$ (including the filter bag). StE is the standard error. The relation is significant at a confidence level of $95 \%$.

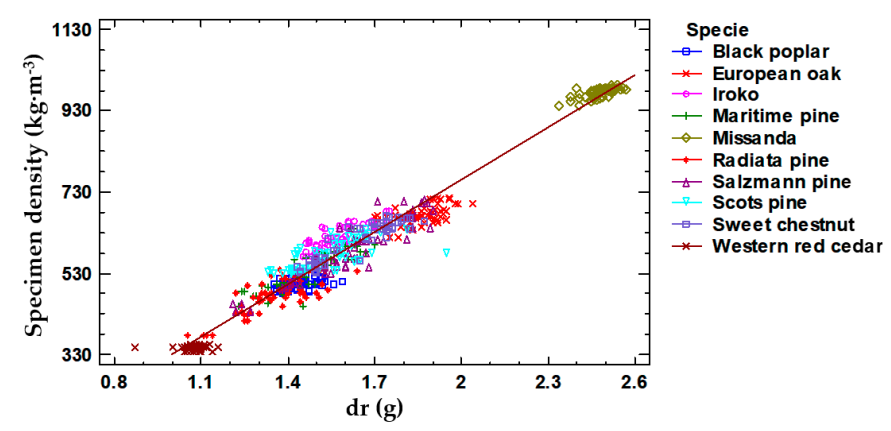

(a)

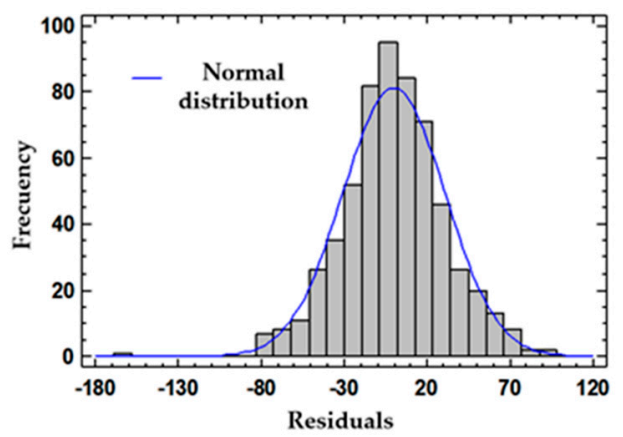

(b)

Figure 7. Linear regression between specimen density and drill residue mass. (a) Plot of the fitted model; (b) Frequency histogram of the model residuals.

The exposed models present almost the same accuracy and standard error as the CDT ( $r^{2}$ 98\%, StE $\left.22 \mathrm{~kg} \cdot \mathrm{m}^{-3}\right)$ [52] but producing a hole $\left(2.4 \mathrm{~cm}^{3}\right)$ equivalent to one-eighth of the volume generated in core extraction $\left(18.8 \mathrm{~cm}^{3}\right)$.

Finally, two linear regression models to estimate softwood and hardwood specimen density separately using drilling residue mass as a predictor variable were developed.In both models, the assumptions of normality, homoscedasticity and linearity were tested. The resulting models are shown in Equations (4) and (5). Where " $\rho$ " is the specimen density in $\mathrm{kg} \mathrm{m}^{-3}$ and " $\mathrm{dr}_{\text {mean }}$ " is the drilling residue mean mass in $\mathrm{g}$ (including the filter bag). StE is the standard error. The relation is significant at a confidence level of $95 \%$.

Softwood model (Western red cedar, Radiata pine, Maritime pine, Scots pine and Salzmann pine).

$$
\rho=433.037 \cdot \mathrm{dr}_{\text {mean }}-109.546 \quad r^{2} 92.78 \%, \mathrm{StE} 26.70 \mathrm{~kg} \cdot \mathrm{m}^{-3}
$$

Hardwood model (Black poplar, Sweet chestnut, European oak, Iroko and Missanda).

$$
\rho=423.696 \cdot d r_{\text {mean }}-86.149 \quad r^{2} 97.06 \%, \text { StE } 27.84 \mathrm{~kg} \cdot \mathrm{m}^{-3}
$$

As can be seen, the models for softwood and hardwood (Equations (4) and (5)) present an $r^{2}$ and a StE similar to the model obtained with the ten species (Equation (2)).

For density estimation in large timber pieces, the author recommends several measurements in different areas due to the variability of wood density within the same piece.

The number of measurements will depend on the overall dimensions of the piece. Bobadilla et al. [29] proposed a measure per meter, and if possible, in different faces. For structural timber members, Osuna-Sequera et al. [54] recommended to carry out a minimum number of three or four measurements using Wood Extractor, commencing readings in the central one-third of the piece (the area of the maximum bending moment)

It is strongly recommended to seal drill holes left in the tested wood by wooden dowels to avoid the laying of xylophagous insect eggs, the penetration of fungi and for aesthetic reasons. 


\section{Conclusions}

Wood density estimation models using drilling residue mass as a predictor were developed using ten softwood and hardwood species with a wide range of densities (from 350 to $960 \mathrm{~kg} \cdot \mathrm{m}^{-3}$ ) The first model considered average sawdust and filter mass as well as radial and tangential directions. It gives a $97.38 \%$ determination coefficient. As no statistically significant difference was found between radial and tangential results, a second model considering sawdust and filter mass while omitting direction was developed, resulting in a determination coefficient of $96.26 \%$.

Given the very high coefficients of determination obtained (97 and 96\%) and the low associated standard errors $\left(26\right.$ and $31 \mathrm{~kg} \cdot \mathrm{m}^{-3}$ ), the drilling chips extraction method can be considered as a determination of wood density rather than an estimation.

The drilling chips extraction technique is as accurate as the core drilling technique for wood density determination but producing eight times less damage.

In summary, drill residue collection is a simple, reliable, accurate, and inexpensive semi-destructive method for wood density estimation and the holes left in the wood do not have a significant effect on the mechanical properties.

\section{Patents}

Martínez R, Bobadilla I (2013) Extractor de muestras de madera mediante taladro (Wood sample extractor using a conventional drill). Spain, ES2525504. (B27C 3/00) (2006.01), 16 Nov 2015. Appl. 201330890, 14 Jul 2013.

Author Contributions: Conceptualization, R.D.M. and I.B.; Data curation, R.D.M.; Formal analysis, R.D.M.; Funding acquisition, I.B.; Investigation, R.D.M.; Methodology, R.D.M.; Project administration, I.B.; Resources, I.B.; Supervision, I.B.; Writing—original draft, R.D.M., J.-A.B. and D.F.L.; Writing—review \& editing, R.D.M., J.-A.B., D.F.L. and I.B. All authors have read and agreed to the published version of the manuscript.

Funding: Ministerio de Economía y Competitividad [Spanish Ministry of Economy and Competitiveness], Programa Estatal I + D, 2013-2016, Proy.: BIA2014-55089-P. Asociación de Investigación Técnica de la Madera (AITIM), Proyect AITIM-Fucovasa 2012-2013 and Proyect AITIM Fucovasa 2014-2015.

Conflicts of Interest: The authors declare no conflict of interest.

\section{References}

1. ICOMOS. Principles for the Preservation of Historic Timber Structures. International Council on Monuments and Sites: Paris, France, 1999. Available online: http://www.international.icomos.org/charters/wood_e. htm2008/02/18 (accessed on 15 February 2020).

2. Kasal, B.; Ronald, W.A. Advances in in situ evaluation of timber structures. Prog. Struct. Eng. Mater. 2004, 6, 94-103. [CrossRef]

3. Esteban, M. Determinación de la Capacidad Resistente de la Madera Estructural de Gran Escuadría y su Aplicación en Estructuras Existentes de Madera de Conífera [Determination of the Load Carrying Capacity of Large Cross Section Structural Coniferous Timber on Existing Structures]. Ph.D. Thesis, Universidad Politécnica de Madrid, Madrid, Spain, September 2003.

4. Schimleck, L.; Dahlen, J.; Apiolaza, L.A.; Downes, G.; Emms, G.; Evans, R.; Moore, J.; Pâques, L.; Van den Bulcke, J.; Wang, X. Non-Destructive Evaluation Techniques and What They Tell Us about Wood Property Variation. Forests 2019, 10, 728. [CrossRef]

5. Š́korpík, P.; Konrad, H.; Geburek, T.; Schuh, M.; Vasold, D.; Eberhardt, M.; Schueler, S. Solid Wood Properties Assessed by Non-Destructive Measurements of Standing European Larch (Larix decidua Mill.): Environmental Effects on Variation within and among Trees and Forest Stands. Forests 2018, 9, 276. [CrossRef]

6. Ponneth, D.; Vasu, A.E.; Easwaran, J.C.; Mohandass, A.; Chauhan, S.S. Destructive and non-destructive evaluation of seven hardwoods and analysis of data correlation. Holzforschung 2014, 68, 951-956. [CrossRef]

7. Basterra, L.A.; Acuña, L.; Casado, M.; Ramón, G.; López, G. Diagnóstico y análisis de estructuras de madera mediante técnicas no destructivas: Aplicación a la Plaza Mayor de Chinchón (Madrid). Inf. Constr. 2009, 61, 21-31. [CrossRef] 
8. Ross, R.J.; Pellerin, R.F. Nondestructive testing for assessing wood members in structures: A review. Gen. Tech. Rep. 1994, FPL-GTR-70, 39-49.

9. Tannert, T.; Anthony, R.W.; Kasal, B.; Kloiber, M.; Piazza, M.; Riggio, M.; Rinn, F.; Widmann, R.; Yamaguchi, N. In situ assessment of structural timber using semi-destructive techniques. Mater. Struct. 2014, 47, 767-785. [CrossRef]

10. Nowak, T.P.; Jasieńko, J.; Hamrol-Bielecka, K. In situ assessment of structural timber using the resistance drilling method-Evaluation of usefulness. Constr. Build. Mater. 2016, 102, 403-415. [CrossRef]

11. Ross, R.J. Nondestructive Evaluation of Wood. Government Printing Office: Madison, WI, USA, 2015; Volume 238.

12. Straže, A.; Fajdiga, G.; Gospodarič, B. Nondestructive Characterization of Dry Heat-Treated Fir (Abies Alba Mill.) Timber in View of Possible Structural Use. Forests 2018, 9, 776. [CrossRef]

13. Fundova, I.; Funda, T.; Wu, H.X. Non-Destructive Assessment of Wood Stiffness in Scots Pine (Pinus sylvestris L.) and its Use in Forest Tree Improvement. Forests 2019, 10, 491. [CrossRef]

14. Arriaga, F.; Garcia, L.; Gebremedhin, K.G.; Peraza, F. Grading and load carrying capacity of old timber beams. In Proceedings of the International Summer Meeting, American Society of Agricultural Engineers, Charlotte, NC, USA, 25-28 June 1992.

15. Calderoni, C.; De Matteis, G.; Giubileo, C.; Mazzolani, F.M. Experimental correlations between destructive and non-destructive tests on ancient timber elements. Eng. Struct. 2010, 32, 442-448. [CrossRef]

16. Jasiénko, J.; Nowak, T.; Hamrol, K. Selected methods of diagnosis of historic timber structures-principles and posibilites of assessment. Adv. Mater. Res. 2013, 778, 225-232. [CrossRef]

17. Divos, F.; Tanaka, T. Lumber strength estimation by multiple regression. Holzforschung 1997, 51, $467-471$. [CrossRef]

18. Ross, R.J.; Soltis, L.A.; Otton, P. Assessing wood members in the USS constitution using non-destructive evaluation methods. APT Bull. J. Preserv. Technol. 1998, 29, 21-25. [CrossRef]

19. Ceccotti, A.; Togni, M. NDT on ancient timber beams: Assessment of strength/stiffness properties combining visual and instrumental methods. In Proceedings of the 10th International Symposium on Nondestructive Testing of Wood, Lausanne, Switzerland, 26-28 August 1996; pp. 379-388.

20. Perellin, R.F.; Ross, R.F.; Beall, F.C.; Bradshaw, B.K.; Cheung, K.; Wang, X. Nondestructive Evaluation of Wood; Forest Products Society: Madison, WI, USA, 2002.

21. Bucur, V. Acoustic of Wood; Springer: Berlin, Germany, 2006. [CrossRef]

22. Meierhofer, U. Schraubenauszugfestigkeit und Tragfähigkeit von Fichten- und Tannenholz. [Screw withdrawal resistance and strength of spruce and fir]. Holz Roh-und Werkstoff 1988, 46, 15-17. [CrossRef]

23. Ishiguri, F.; Matsui, R.; Iizuka, K.; Yokota, S.; Yoshizawa, N. Prediction of the mechanical properties of lumber by stresswave velocity and Pilodyn penetration of 36-year-old Japanese larch trees. Holz Roh-und Werkstoff 2008, 66, 275-280. [CrossRef]

24. Kharrat, W.; Koubaa, A.; Khlif, M.; Bradai, C. Intra-Ring Wood Density and Dynamic Modulus of Elasticity Profiles for Black Spruce and Jack Pine from X-Ray Densitometry and Ultrasonic Wave Velocity Measurement. Forests 2019, 10, 569. [CrossRef]

25. Chen, Y.; Guo, W. Mechanical properties evaluation of two wood species of ancient timber structure with nondestructive testing methods. BioResources 2016, 11, 6600-6612. [CrossRef]

26. Kloiber, M.; Tippner, J.; Hrivnák, J. Mechanical properties of wood examined by semi-destructive devices. Mater. Struct. 2014, 47, 199-212. [CrossRef]

27. Kobayashi, K.; Hwang, S.W.; Okochi, T.; Lee, W.H.; Sugiyama, J. Non-destructive method for wood identification using conventional X-ray computed tomography data. J. Cult. Herit. 2019, 38, 88-93. [CrossRef]

28. Simic, K.; Gendvilas, V.; O’Reilly, C.; Harte, A.M. Predicting structural timber grade-determining properties using acoustic and density measurements on young Sitka spruce trees and logs. Holzforschung 2019, 73, 139-149. [CrossRef]

29. Bobadilla, I.; Íñiguez-González, G.; Esteban, M.; Arriaga, F.; Casas, L. Density estimation by screw withdrawal resistance and probing in structural sawn coniferous timber. In Proceedings of the 15th International Symposium on Nondestructive Testing of Wood, Duluth, MN, USA, 10-12 September 2007; pp. 247-251. 
30. Montón, J. Clasificación Estructural de la Madera de Pinus radiata D. Don Procedente de Cataluña Mediante Métodos no Destructivos y su Aplicabilidad en la Diagnosis Structural [Structural Timber Grading of Pinus radiata D. Don from Catalonia Using NDT and Applicability in Structural Assessment]. Ph.D. Thesis, Universidad Politécnica de Cataluña, Barcelona, Spain, October 2012.

31. Casado, M.; Acuña, L.; Basterra, L.A.; Ramón-Cueto, G.; Vecilla, D. Grading of structural timber of Populus $x$ euroamerica clone I-214. Holzforschung 2012, 66, 633-638. [CrossRef]

32. Sharapov, E.; Wang, X.; Smirnova, E.; Wacker, J.P. Wear behavior of drill bits in wood drilling resistance measurements. Wood Fiber Sci. 2018, 50, 154-166. [CrossRef]

33. Karlinasari, L.; Danu, M.I.; Nandika, D.; Tujaman, M.; Bogor, D.; Ipb, K. Drilling resistance method to evaluate density and hardness properties of resinous wood of agarwood (Aquilaria malaccensis). Wood Res.-Slovakia 2017, 6, 683-690.

34. Iñiguez-González, G.; Arriaga, F.; Esteban, M.; Bobadilla, I.; González, C.; Martínez, R.D. In situ non-destructive density estimation for the assessement of existing timber structures. In Proceedings of the 10th World Conference Timber Engineering, Riva di Garda, Italy, 20-24 June 2010; pp. 1124-1149.

35. Faggiano, B.; Marzo, A. A method for the determination of the timber density through the statistical assessment od ND transverse measurements aimed at in situ mechanical identification of existing timber structures. Constr. Build. Mater. 2015, 101, 1235-1240. [CrossRef]

36. Lourenco, P.B.; Feio, A.O.; Machado, J.S. Chesnut wood in compression perpendicular to the grain: Non-destructive correlations for test results in new and old wood. Constr. Build. Mater. 2007, 21, 1617-1627. [CrossRef]

37. López, G.; Basterra, L.A.; Acuña, L. Infrared thermography for wood density estimation. Infrared Phys. Techn. 2018, 89, 242-246. [CrossRef]

38. Mariño, R.; Fernández, M.E.; Fernández, C. Análisis comparativo de la densidad de la madera de Pinus sylvestris L. mediante la utilización del resistógrafo [Comparative análisis of wood density from Pinus sylvestris L. using resistograph]. Revista CIS-Madera 2002, 9, 60-70.

39. Kloiber, M.; Kotlínová, M. Prediction of mechanical properties by means of radial cores in situ, NSF/MŠMT supported US-Czech project and RILEM Workshop. In Proceedings of the In-Situ Evaluation of Historic Wood and Masonry Structures, Prague, Czech Republic, 10-14 July 2006.

40. Rinn, F.; Schweingruber, F.H.; Schär, E. Resistograph and X-ray density charts of wood. Comparative evaluation of drill resistance profiles and X-ray density charts for different wood species. Holzforschung 1996, 50, 303-311. [CrossRef]

41. Acuña, L.; Basterra, L.A.; Casado, M.; López, G.; Ramón-Cueto, G.; Relea, E.; Martínez, C.; González, A. Aplicación del resistógrafo a la obtención de la densidad y la diferenciación de especies de madera [Application of resistograph to obtain the density and to differentiate wood species]. Mater. Construcc. 2011, 61, 451-464. [CrossRef]

42. Sharapov, E.; Brischke, C.; Militz, H.; Toropov, A. Impact of drill bit feed rate and rotational frequency on the evaluation of wood properties by drilling resistance measurements. Int. Wood Prod. J. 2019, 10, 1-11. [CrossRef]

43. Bethge, K.; Mattheck, C.; Hunger, E. Equipment for detection and evaluation of incipient decay in trees. Arboric J. 1996, 20, 13-37. [CrossRef]

44. Kasal, B. Semi-destructive method for in-situ evaluation of compressive strength of wood structural members. For. Prod. J. 2003, 53, 55-58.

45. Morales Conde, M.J.; Rodríguez-Liñán, C.; Saporiti-Machado, J. Predicting the density of structural timber members in service. The combine use of wood cores and drill resistance data. Mater. Constr. 2014, 64, 1-11. [CrossRef]

46. Íñiguez-González, G.; Montón, J.; Arriaga, F.; Segués, E. In-situ assessment of structural timber density using non-destructive and semi-destructive testing. BioResources 2015, 10, 2256-2265. [CrossRef]

47. Llana, D.F.; Íñiguez-González, G.; Montón, J.; Arriaga, F. In-situ density estimation by four nondestructive techniques on Norway spruce from built-in wood structures. Holzforschung 2018, 72, 871-879. [CrossRef]

48. Martínez, R.D.; Bobadilla, I. Extractor de Muestras de Madera Mediante Taladro (Wood Sample Extractor Using a Conventional Drill). Patent No. ES2525504, 16 November 2015. 
49. Bobadilla, I.; Martínez, R.D.; Calvo, J.; Arriaga, F.; Íñiguez-González, G. First steps in wood density estimation using a conventional drill. In Proceedings of the 18th International Nondestructive Testing and Evaluation of Wood Symposium, Madison, WI, USA, 24-27 September 2013; pp. 112-118.

50. Martínez, R.D.; Calvo, J.; Arriaga, F.; Bobadilla, I. In situ density estimation of timber pieces by drilling residue analysis. Eur. J. Wood Prod. 2018, 76, 509-515. [CrossRef]

51. Ruy, M.; Gonçalves, R.; Martínez, R.D.; Bertolo, C.; Mansini, R.; Leite, M. First steps in wood density estimation using a conventional drill. In Proceedings of the 21th International Nondestructive Testing and Evaluation of Wood Symposium, Freiburg im Breisgau, Germany, 24-27 September 2019; pp. 162-166.

52. Bobadilla, I.; Martínez, R.D.; Esteban, M.; Llana, D.F. Estimation of wood density by the core drilling technique. Holzforschung 2018, 72, 1051-1056. [CrossRef]

53. Bues, C.T.; Schulz, F.; Eichenseer, F. Untersuchung des Ausziehwiderstands von Nägeln und Schrauben in Kiefernholz [Comparative investigations on the withdrawal resistance of nails and screws in pine]. Holz Roh-und Werkstoff 1987, 45, 514.

54. Osuna-Sequera, C.; Llana, D.F.; Esteban, M.; Arriaga, F. Improving density estimation in large cross-section timber from existing structures optimizing the number of non-destructive measurements. Constr. Build. Mater. 2019, 211, 199-206. [CrossRef]

(C) 2020 by the authors. Licensee MDPI, Basel, Switzerland. This article is an open access article distributed under the terms and conditions of the Creative Commons Attribution (CC BY) license (http://creativecommons.org/licenses/by/4.0/). 